\title{
$p 77-10225$
}

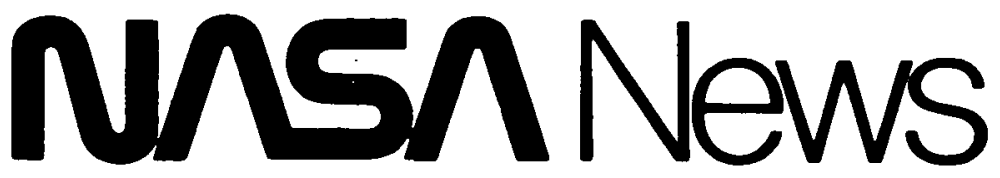

Natıonal Aeronautics and

Space Admınıstration

Washington. D.C. 20546

AC $202755-8370$

For Release

Miles Waggoner

Headquarters, Washington, D.C.

(Phone: 202/755-8370)

IMME.DIATE

RELEASE NO: 77-228

NASA ANNOUNCES REORGANIZATION

NASA Administrator Dr. Robert A. Frosch today announced a planned reorganization of the agency, effective Nov. 8 . The agency's new organization plan would affect NASA nationwide, in all of its operating centers and facilities.

"The intent of the new plan is to strengthen NASA organization and improve our effectiveness," Dr. Frosch said. "In implementing this change, we will reduce the number of staff

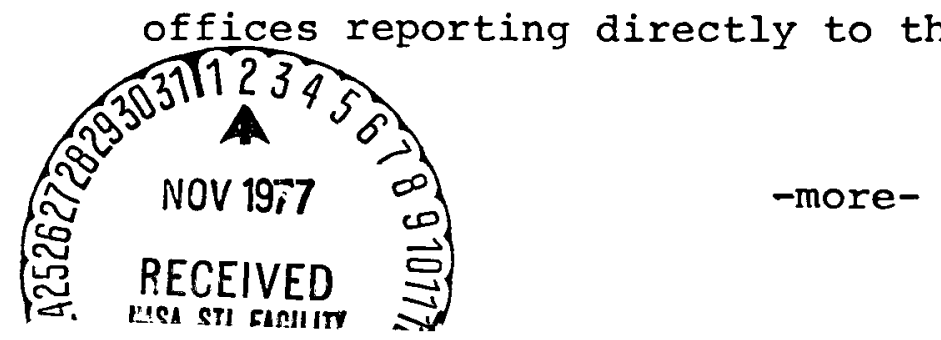

Mailed:

October 26, 1977

(NASA-News-Release-77-228) NASA ANNOUNCES REORGANIZATION (National Aeronautics and Space Adninistration) $8 \mathrm{p}$

N77-86200 
Frosch listed the main objectives prompting the changes :

- To simplify Headquarters organization structure and reduce the number of people in Headquarters.

- To reduce the number of staff offices reporting to the Administrator.

- To establish an integrated interface to agencies and institutions and to the general public through an Office of Fxternal Relations.

- To provide a direct line management relationship between the Administrator and Headquarters program offices.

- To establish a direct reporting relationship between Center Directors and the Administrator.

- To establish a position of Chief Scientist to promote across-the-board agency cognizance over scientific affairs and interaction with the scientific community.

The new look in agency reorganization divides Headquarters operations into three functions:

- The Office of the Administrator, for general management;

- The Chief Scientist, Chief Engineer and five program offices, for program planning, management and review; and

- Eight staff offices to provide program, staff and functional support. 
General Management

The Office of the Administrator includes the Administrator and four top management officials:

- The Deputy Administrator -- acts with or for the Administrator over the full scope of his responsibilities.

- The Assistant to the Deputy Administrator -- responsible for overall coordination of staff activities.

- The Executive officer -- assists the Administrator in arranging and managing his day-to-day activities.

- The Assistant for Special Projects -- provides direct support of specialized activities requiring the Administrator's personal attention.

Heads of all program offices, field centers and the National Space Technology Laboratories will report directly to the Administrator.

\section{Program Planning, Management and Reviev}

This office includes:

- The Chief Scientist -- (a revised role and title for the Associate Administrator) is responsible for advising the Administrator on the agency's total program from the standpoint of scientific objectives. Provides direct interface with various scientific advisory committees.

- The Chief Engineer -- (an existing position) is responsible for the technical execution of all agency programs, assuring that development efforts and mission operations incorporate sound engineering and implement proper controls. Pending further study, reliability and quality assurance and the Low Cost Systems Program are his responsibility. 
Five program Associate Administrators have been designated to implement the Chief Scientist and Chief Engineer's responsibilities in the following fields:

- Aeronautics and Space Technology

- Space Sciences

- Space and Terrestrial Applications (formerly Applications)

- Space Transportation Systems (formerly Space Flight)

- Space Tracking and Data Systems (formerly Tracking and Data Acquisition)

Program, Staff and Functional Support

All support functions, at Headquarters and agencywide, will be the responsibility of eight staff officials with the following titles:

- General Counsel -- provides full scope of legal services to the Administrator.

- Comptroller -- support for allocation and control of appropriations, financial accounting, reporting all agency funds, overall facilities management, including new construction.

- Associate Administrator for Management Operations -provides agency level support in the areas of personnel, labor relations, operation of field centers, information systems, equal opportunity, functions, contract appeals and inventions and contributions board. 
- Associate Administrator for External Relations Ta new position replacing former Associate Administrator for External Affairs) -- provides support to the Administrator for external policy and non-program functions, including: public affairs, legislative affairs, international affairs, interagency and community affairs, university affairs. officials heading these offices will carry the title Director. (The previous designation, Assistant Administrator, has been abolished.)

- Director of Equal Opportunity -- is responsible for appropriate employment policies related to minority applicants and employees.

- Director of Procurement -- provides procurement management support to the Administrator.

- Director of Inspections and Security -- provides functional support to Administrator in these areas.

- Director of Audit (formerly Director of Management Audit) - continues to provide support to Administrator in the area indicated.

Some Significant Changes Under New Plan (Summary)

Elimination of some present titles and restructuring under the new organization plan result in a number of changes, including :

The position of Assistant Administrator for Planning and Program Integration is abolished and responsibilities are reassigned to the Chief Scientist and the Associate Administrator for Space and Terrestrial Applications. 
The position of Assistant Administrator for Institutional Management is abolished and responsibilities are reassigned to the Associate Administrator for Management Operations, except for Headquarters Procurement Operations which is reassigned to the Director of Procurement.

The position of Assistant Administrator for Industry Affairs and Technology Utilization is abolished and responsibilities are reassigned among the Associate Administrators for External Relations, Management operations and Space and Terrestrial Applications and the Chief Engineer.

The position of Assistant Administrator for Energy Programs is abolished and responsibilities are reassigned to the Associate Administrator for Aeronautics and Space Technology.

The position of Assistant Administrator for Personnel Programs is retitled Director of Personnel Programs and responsibilities are restructured under the Associate Administrator for Management Operations.

The position of Assistant Administrator for DOD and Interagency Affairs is abolished and responsibilities are reassigned to the Associate Administrator for Fxternal Relations. 


$$
-7-
$$

The Office of Systems Management is abolished and responsibilities are restructured under the Associate Administrator for Management Operations.

The Office of Program Assurance is abolished and responsibilities are reassigned to the Chief Engineer pending further study. 


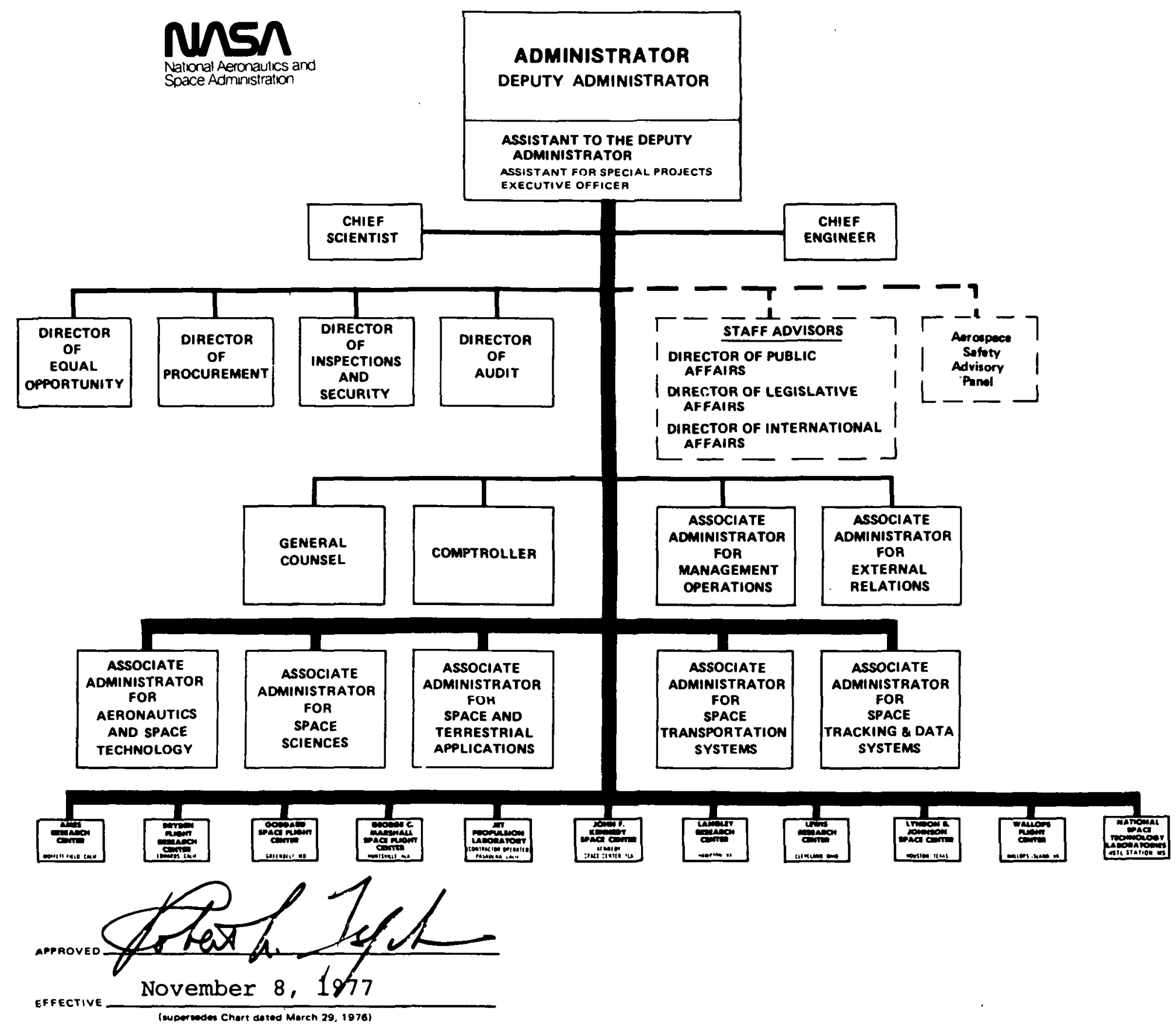

